J. Clin. Chem. Clin. Biochem.

Vol. 28, 1990, pp. $391-398$

(C) 1990 Walter de Gruyter \& Co. Berlin · New York

\title{
Magnitude and Kinetics of Alterations in Plasma Catecholamines and Leukocyte $\beta$-Adrenergic Receptors in Response to Anaesthesia and Surgery ${ }^{1}$ )
}

\author{
By D. Ratge ${ }^{1}$, A. Wiedemann ${ }^{\prime}, K$. P. Kohse ${ }^{1}, H$. Klar $^{2}, K$. Hellberg $^{3}$ and H. Wisser ${ }^{1}$ \\ Departments of ${ }^{1}$ Clinical Chemistry, ${ }^{2}$ Anaesthesiology, and ${ }^{3}$ Cardiovascular Surgery, Robert-Bosch-Krankenhaus, \\ Stuttgart (Federal Republic of Germany)
}

(Received May 30/September 27, 1989//February 6, 1990)

\begin{abstract}
Summary: We studied the response of the sympatho-adrenal system to varying intensities of different stimuli. Concentrations of norepinephrine and epinephrine in plasma as well as densities of $\beta_{2}$-adrenergic receptors on mononuclear leukocytes were determined in patients subjected to operations of varying complexity and different types of anaesthesia.
\end{abstract}

In patients undergoing hysterectomy $(\mathrm{n}=9)$, the maximal increases in plasma norepinephrine and epinephrine were 2.7- and 2.8-fold, respectively, corresponding to a post-operative decrease of the mononuclear leukocyte $\beta_{2}$-adrenergic receptors of $27 \%$ after 4 hours.

Patients with coronary revascularization $(n=17)$ were randomly selected to receive either enflurane/ $\mathrm{N}_{2} \mathrm{O}$ or neurolept anaesthesia. During intraoperative periods of stress, such as cardiopulmonary bypass and hypothermia, norepinephrine and epinephrine levels were 2-3 times higher in the neurolept patients, compared with the enflurane patients. In the former group, the respective maximal norepinephrine and epinephrine concentrations were 9.7 and 28 times the vasal values of the non-anaesthetized patients. One day postoperatively, the mononuclear leukocyte $\beta_{2}$-receptor density decreased maximally by $45 \pm 11 \%$ in the enflurane patients, and by $53 \pm 6 \%$ in the neurolept patients. As early as two to five days after cardiac surgery, $\beta_{2^{-}}$ receptor densities were no longer distinguishable from the preoperative values. Significant correlations between the increases in catecholamine concentrations and the decreases in $\beta_{2}$-receptor densities did not exist.

It is concluded that enflurane blocks the sympatho-adrenal response to surgical stress more effectively than neurolept anaesthesia. In addition to the increases in catecholamine concentrations, other factors must contribute to the postoperative decrease in mononuclear leukocyte $\beta_{2}$-receptor densities. Such factors may include endotoxin production, or an alteration of the receptor in the membrane due to the action of the different narcotics on the lipid phase of the membrane.

\section{Introduction}

Mononuclear leukocytes are easily accessible cells for investigations on the regulation of $\beta$-adrenergic receptors in man. Several studies on mononuclear leukocytes have demonstrated that changes in the density

1) On the occasion of the $25^{\text {th }}$ anniversary of the German Society for Clinical Chemistry (cf. Editorial, this J. 27, 529 (1989)) of $\beta$-receptors and changes in the response to adrenergic stimuli reflect those on other tissues $(1,2)$. Following the prolonged administration of $\beta$-adrenergic agonists (3), receptor-mediated responses become blunted, and the density of leukocyte $\beta_{2}$-adrenergic receptors decreases significantly, i.e., the cells are desensitized. This agonist-promoted desensitization includes a rapid (within a few minutes) redistribution or internalization of surface $\beta$-receptors into mem- 
brane vesicles, where the receptors are uncoupled from the catalytic unit of adenylate cyclase, followed by a slow (within hours or days) degradation of internal receptors leading to a decrease in their total number (surface plus internal) $(4,5)$. Such a decrease of mononuclear leukocyte $\beta_{2}$-receptors has previously been reported following chronically elevated plasma catecholamine concentrations in patients with phaeochromocytoma (6), while receptor up-regulations were observed in response to chronically depressed concentrations of catecholamines as found in patients with orthostatic hypotension (7).

There are fewer reports of changes of adrenoceptors following acute exposure to elevated catecholamine concentrations, and the data are less consistent. In the majority of the reported animal studies, the agonist concentrations used were very high (approximately 100 times the basal catecholamine levels (8). In man, sudden increases in catecholamines induced by exercise result first in an increase, later in a decrease of total mononuclear leukocyte $\beta_{2}$-adrenergic receptors $(9,10)$. The former process could be explained by the lymphocytosis resulting from the exercise and the corresponding shift in the ratio of $\mathrm{B}$ - and $\mathrm{T}$ lymphocytes (11), taking into account the higher $\beta_{2^{-}}$ receptor densities on B-cells compared with T-lymphocytes (12). A postural change (upright posture for $3 \mathrm{~h}$ ) or the infusion of isoproterenol for $120 \mathrm{~min}$, leading to a mean plasma epinephrine concentration of $2.8 \pm 0.5 \mathrm{nmol} / 1$ and to heart rate elevations of 40-50 $\mathrm{min}^{-1}$, did not influence the total number of $\beta$-receptors on mononuclear leukocytes (5). A significant reduction in the number of binding sites, however, was reported in patients $24 \mathrm{~h}$ after surgery (13).

The purpose of this study was to explore the consequences of an activation of the sympathetic-adrenomedullary system during surgical stress (14) with respect to the density of $\beta_{2}$-receptors in mononuclear leukocytes. In particular, we have investigated whether operations of different complexity (hysterectomy vs. coronary artery bypass), as well as different types of anaesthesia (enflurane/ $\mathrm{N}_{2} \mathrm{O}$ vs. fentanyl) with known variable effects on plasma catecholamine concentrations (15), result in different changes in the densities of mononuclear leukocyte $\beta_{2}$-receptors.

\section{Materials and Methods}

Patients

After approval had been given by the Ethical Committee of the Robert-Bosch-Hospital, informed consent was obtained from 9 patients scheduled for hysterectomy (group I) and from 17 patients assigned for elective cardiac surgical procedures. The latter were operated for coronary revascularization and were randomly selected to receive either enflurane $/ \mathrm{N}_{2} \mathrm{O}$ (group II) or neurolept anaesthesia (group III). Both groups were comparable with respect to age, weight and total operation and cardiopulmonary bypass time. All patient data are given in table 1 None had hypertension, diabetes, or any associated disease. The patients scheduled for hysterectomy and for cardiac surgery received no drugs during the four weeks before the operation.

Tab. 1. Patient data (mean \pm SEM)

\begin{tabular}{|c|c|c|c|}
\hline \multirow[t]{2}{*}{ Parameter } & \multirow{2}{*}{$\begin{array}{l}\text { Hysterectomy } \\
\text { Neurolept } \\
\text { anaesthesia } \\
+ \text { Enflurane }\end{array}$} & \multicolumn{2}{|c|}{ Cardiac surgery } \\
\hline & & Enflurane & $\begin{array}{l}\text { Neuro- } \\
\text { lept } \\
\text { anaes- } \\
\text { thesia }\end{array}$ \\
\hline Number & 9 & 9 & 8 \\
\hline Male/female & $-/ 9$ & $9 /-$ & $8 /-$ \\
\hline Age (years) & $47 \pm 3$ & $56 \pm 3$ & $55 \pm 3$ \\
\hline Weight (kg) & $63 \pm 4$ & $78 \pm 3$ & $80 \pm 4$ \\
\hline $\begin{array}{l}\text { Total operation } \\
\text { time (min) }\end{array}$ & $133 \pm 12$ & $330 \pm 16$ & $332 \pm 20$ \\
\hline $\begin{array}{l}\text { Cardiopulmonary } \\
\text { bypass time } \\
\text { (min) }\end{array}$ & - & $118 \pm 10$ & $133 \pm 10$ \\
\hline
\end{tabular}

\section{Anaesthesia}

For premedication, patients in group I received pethidine $(0.5-$ $0.7 \mathrm{mg} / \mathrm{kg})$, atropine $(0.7-1 \mu \mathrm{g} / \mathrm{kg})$ and trifluorpromazine $(0.2$ $\mathrm{mg} / \mathrm{kg})$. Intravenous fentanyl $(0.5 \mu \mathrm{g} / \mathrm{kg})$ and droperidol $(5-7.5$ $\mathrm{mg}$ ) were given for induction of the anaesthesia, and 0.3 to $1.0 \%$ inspired enflurane for its maintenance. Intravenously administered pancuronium was used for muscle relaxation. Depending on the haemodynamic response, fentanyl was injected additionally in doses of $0.1 \mathrm{mg}$. Within $10 \mathrm{~min}$ after completion of the surgical procedure, extubation was performed. No medication was administered to reverse muscle paralysis. Blood samples were obtained 1 day before the operation (S1), following the induction of anaesthesia (S2), at the end of the operation (S3), $4 \mathrm{~h}$ after arrival in the recovery room (4S), and 1 day (S5) and 2-3 days (S6) following surgery.

All cardiac surgery patients received diazepam $(10 \mathrm{mg})$, pethidine $(0.5-1.0 \mathrm{mg} / \mathrm{kg})$, and promethazine $(0.5-1.0 \mathrm{mg} / \mathrm{kg})$ as preoperative medication. In addition, the patients in group III were given droperidol $(2.5-5 \mathrm{mg})$. All patients received pancuronium $(0.1 \mathrm{mg} / \mathrm{kg})$ for muscle relaxation.

Patients in group II received fentanyl $(5-10 \mu \mathrm{g} / \mathrm{kg})$ and enflurane for induction of the anaesthesia. With loss of consciousness and loss of palpable reflexes, the patients were ventilated with $50 \% \mathrm{O}_{2}$ and $50 \%$ nitrous oxide. Enflurane $(1.5-2 \%)$ was added depending on the haemodynamic response.

Patients in group III were anaesthetized with $5-10 \mu \mathrm{g} / \mathrm{kg}$ of fentanyl and $0.1-0.25 \mathrm{mg} / \mathrm{kg}$ of droperidol. Anaesthesia was maintained with $50 \% \mathrm{O}_{2}$ and $50 \%$ nitrous oxide with addition of fentanyl depending on the haemodynamic response of the individual patient.

At the completion of the surgical procedure, no medication was administered to reverse muscle paralysis. Extubation was performed only when the patient was breathing spontaneously and comfortably as judged by measurement of blood gases ( 4.8 to $19.4 \mathrm{~h}$, mean $9.5 \mathrm{~h}$, following operation). Postoperative analgesia was maintained by intravenous pethidine as required for the patients' comfort. There were no episodes of excessive blood 


\section{Peptides 1988}

\section{Proceedings of the 20th European Peptide Symposium}

September 4-9, 1988 - University of Tübingen

Tiubingen, Federal Republic of Germany

1989. $17 \times 24 \mathrm{~cm}$. LX, 795 pages. With numerous illustrations.

Hardcover. DM 386,-; approx. US \$ 193.00 ISBN 3110109492

The development of peptide chemistry and its increased importance in various fields of biochemistry, biology and medicine has been well documented in the Proceedings

of the European Peptide Symposia.

Peptides 1988 presents contributions from scientists all over the world to the 20th Peptide Symposium.

\section{From the Contents}

Methodology of Synthesis - Peptides with Unusual and Modified Residues · Physical Studies on Peptides · Hormones, Receptors and Structure-Activity Relationships · Immunochemistry $\cdot$ Author Index $\cdot$ Subject Index

Also available:

\section{Peptides 1982}

Editors Blàha, Malǒn

1983. $17 \mathrm{~cm} \times 24 \mathrm{~cm}$. LVI, 846 pages. DM 280,- ISBN 3110095742

\section{Peptides 1986}

Editor Theodoropoulos

1987. $17 \mathrm{~cm} \times 24 \mathrm{~cm}$. XIX, 684 pages. DM 320,- ISBN 3110106876 


\section{Wilhelm Friedrich}

\section{Vitamins}

1988. $17 \mathrm{~cm} \times 24 \mathrm{~cm}$. XII, 1062 pages. Hardcover. DM 380,-; approx. US $\$ 225.00$ ISBN 3110101447

A comprehensive, authoritative Handbook and reference source of all aspects of vitamins.

The book at a glance

- Complete and systematic overview of all water- and fat-soluble vitamins

- Introductory chapter presenting basic general information on the vitamins

- Numerous illustrations, formulas, tables, etc.

- Comprehensive and up-to-date bibliographic references at the end of each chapter

- Supplementary bibliography of publications that appeared subsequent to completion of the editorial work on the book

\section{From the Contents}

Introduction - Vitamin A and its Provitamins - Vitamin D - Vitamin E - Vitamin K . Thiamin (Vitamin $\mathbf{B}_{1}$, Aneurin) · Vitamin $\mathrm{B}_{2}$ : Riboflavin and its Bioactive Variants Niacin: Nicotinic Acid, Nicotinamide, NAD (P) $\cdot$ Vitamin $B_{6} \cdot$ Folic Acid and Unconjugated Pteridines · Biotin · Pantothenic Acid - Vitamin $B_{12} \cdot$ Vitamin C . Literature Supplement $\cdot$ Subject Index

\section{Potential audience}

Biochemists, Biologists, Clinicians, Pharmacologists, Toxicologists, Physiologists, Pharmacists, Nutritionists, Organic and Analytical Chemists. Institutes, Libraries

Price is subject to change without notice

\section{W de Gruyter · Berlin · New York}


losses, but blood transfusions ( 500 to $1500 \mathrm{ml}$ ) were administered in 14 cases during the investigation period. Postoperatively, dopamine $(6 \mu \mathrm{g} / \mathrm{kg} \cdot \min )$ had to be infused in 2 cases for $6 \mathrm{~h}$ and $12 \mathrm{~h}$, respectively, to overcome cardiovascular depressions. Blood samples for the determination of catecholamines, cortisol (S1 to S20) and mononuclear leukocyte $\beta_{2^{-}}$ receptor density ( $\mathrm{S}^{*}$ to $\mathrm{S} 20^{*}$ ) were drawn according to the scheme shown in table 2 .

Tab. 2. Sampling points for measurement of hormone concentrations $(\mathrm{S} 1-\mathrm{S} 20)$ and mononuclear leukocyte $\beta_{2}$-receptor densities $\left(\mathrm{Sx}^{*}\right)$ in cardiac surgery

$\begin{array}{ll}\text { S1* } & \text { preoperative day } \\ \text { S2 } & 50 \text { min following premedication } \\ \text { S3* } & 1 \text { min after intubation } \\ \text { S4 } & 1 \text { min after sternotomy } \\ \text { S5 } & 5 \text { min after pericardotomy } \\ \text { S6 } & 5 \text { min following cardiopulmonary bypass } \\ \text { S7* } & \text { starting steady state of hypothermia } \\ \text { S8 } & 30 \text { min later } \\ \text { S9* } & \text { start of the warming up } \\ \text { S10 } & \text { 20 min later } \\ \text { S11 } & \text { release of aortic cross-clamping } \\ \text { S12 } & \text { attainment of rectal temperature of } 34^{\circ} \mathrm{C} \\ \text { S13* } & \text { completion of the cardiopulmonary bypass } \\ \text { S14 } & \text { completion of the surgical procedure } \\ \text { S15 } & 30 \text { min after arrival in the intensive care unit } \\ \text { S16* } & 2 \text { to } 4 \text { h later } \\ \text { S17* } & 5 \text { min after extubation } \\ \text { S18* } & 1 \text { day postoperatively } \\ \text { S19* } & 2 \text { days postoperatively } \\ \text { S20* } & 4 \text { to } 5 \text { days postoperatively }\end{array}$

\section{Analytical methods}

Samples of venous blood $(2-6 \mathrm{ml})$ were drawn into tubes containing EDTA $(0.1 \mathrm{~g} / \mathrm{l}$ blood). Differential cell counts were performed on blood smears stained with a May-GrünwaldGiemsa stain. B and T lymphocytes were recognized using the Immunogold Cell Labeling System (Geometric Data, Munich) according to Rosenberg et al. (16). For hormone determinations, $2 \mathrm{ml}$ of blood were centrifuged at $4{ }^{\circ} \mathrm{C}$ within $1 \mathrm{~h}$ and stored at $-20^{\circ} \mathrm{C}$ until analysis. Concentrations of free catecholamines in plasma were measured with a single isotope derivative method employing $50 \mu \mathrm{l}$ samples (17). Plasma cortisol concentrations were measured with a radioimmunoassay kit (Diagnostic Products Corp., Houston, USA).

Details of the methods for cell separation and receptor binding analysis have been given elsewhere (18). In brief, mononuclear leukocytes were isolated from $4 \mathrm{ml}$ blood by Ficoll density gradient centrifugation, followed by thorough washing of the cell fraction with phosphate-buffered saline. A May-GrünwaldGiemsa stain of the preparations revealed different portions of lymphocytes $(50-80 \%)$ and monocytes $(50-20 \%)$ and virtually no erythrocytes or neutrophilic granulocytes. More than $90 \%$ of the cells were viable as judged by the ability to exclude Trypan Blue.

For the determination of the total $\beta_{2}$-adrenergic receptor density, an aliquot of the cell suspension $(0.1 \mathrm{ml}$, approximately $1-2.5 \times 10^{5}$ cells) was incubated with six different concentrations $(6-80 \mathrm{pmol} / \mathrm{l})$ of $(-)\left[{ }^{125} \mathrm{I}\right]$ iodocyanopindolol in $0.4 \mathrm{ml}$ incubation buffer $\left(37.5 \mathrm{mmol} / 1\right.$ Tris/ $\mathrm{HCl}, 7.5 \mathrm{mmol} / 1 \mathrm{MgCl}_{2}$, $1.5 \mathrm{mmol} / \mathrm{l}$ ascorbic acid, $\mathrm{pH}$ 7.6). Incubation in a total volume of $0.6 \mathrm{ml}$ was performed for $60 \mathrm{~min}$ at $37^{\circ} \mathrm{C}$ in a shaking water bath. Samples were rapidly filtered by vacuum suction, and the radioactivity retained on Whatman GF/C filters (Vetter, Wiesloch, FRG) was determined.
To assess the non-specific binding, the lipophilic unlabelled antagonist, $( \pm)$ propranolol, was used at a final concentration of $1 \mu \mathrm{mol} / \mathrm{l}$. Specific binding was defined as the difference between total and non-specific binding in the presence of propranolol, and it was generally in the range of $65-75 \%$ of the total binding. With this method, saturable binding to the cells was observed; furthermore, after transformation of the data according to Scatchard, linear plots were obtained (11). Maximal densities of binding sites $\left(\mathrm{B}_{\max }\right)$ and equilibrium dissociation constants $\left(\mathrm{K}_{\mathrm{D}}\right)$ were calculated using a nonlinear iterative curve fitting program. The intra-assay coefficient of variation for the determination of receptor densities was found to be $9 \%$ when receptor densities were within the normal range.

The values in the text and figures are given as mean $\pm S$. E. M. For comparison of mean values, the data were evaluated by the Friedman two-way analysis of variance. Relationships between two variables were investigated by linear regression analyses. Values of the area under the curve were calculated according to the trapezoidal rule from the corresponding concentration-time profiles.

\section{Results}

The pre-, intra- and post-hysterectomy concentrations of norepinephrine and epinephrine in plasma, together with the mononuclear leukocyte $\beta_{2}$-receptor densities, are expressed graphically in figure 1 (group I). The baseline or control (preoperative) levels of norepi-
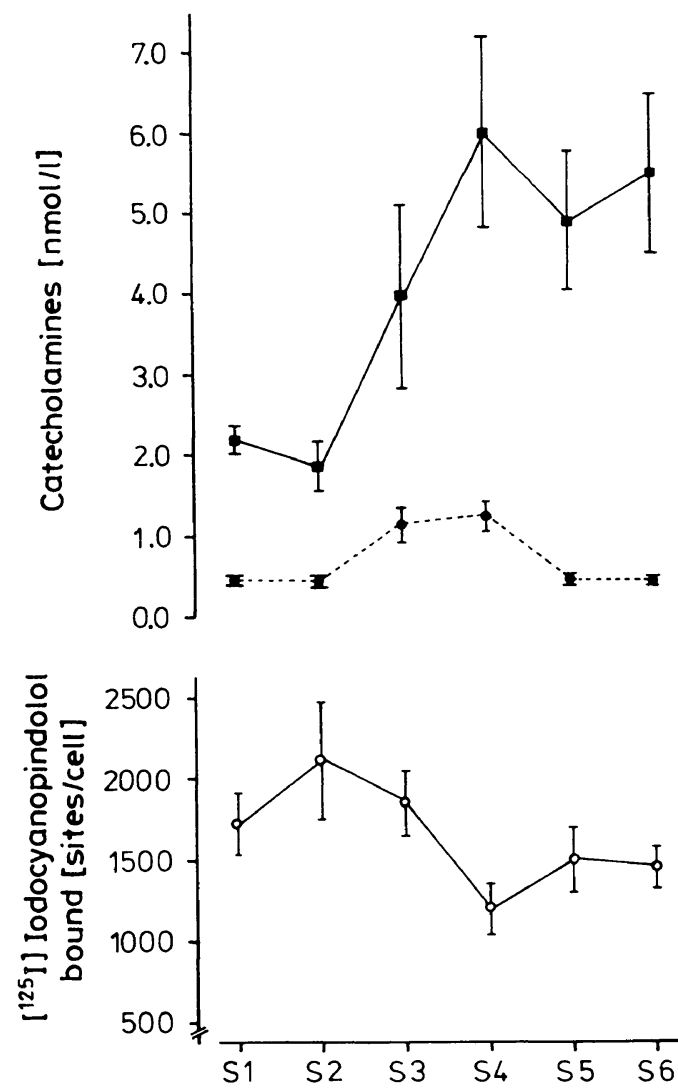

Fig. 1. Time course of plasma catecholamine concentrations (squares, norepinephrine; closed circles, epinephrine) and mononuclear leukocyte $\beta_{2}$-receptor densities (open circles) in patients prior to, during and after hysterectomy. The sampling points, $\mathrm{S} 1-\mathrm{S} 6$, are given in the methods section. 
nephrine $(2.2 \pm 0.14 \mathrm{nmol} / \mathrm{l})$ and epinephrine $(0.45$ $\pm 0.02 \mathrm{nmol} / \mathrm{l})$ were within the normal range. The increases of plasma norepinephrine and epinephrine in response to the surgical stress were maximally $2.7-$ and 2.8-fold, respectively. It can be seen (fig. 1) that while the epinephrine level rapidly returned to the baseline value (within $24 \mathrm{~h}$ of operation), the norepinephrine level remained elevated throughout the $2-3$ days of the postoperative period. The $\beta_{2}$-receptor density $(1705 \pm 200$ binding sites per cell preoperatively) showed the lowest level 4 hours postoperatively ( 1240 \pm 160 binding sites per cell; not significantly different from the preoperative value) and returned to baseline values within $24 \mathrm{~h}$.

The mean plasma norepinephrine and epinephrine levels, as well as the mononuclear leukocyte $\beta_{2}$-receptor densities during and following cardiac surgery, are shown in figure 2 for group II (patients under enflurane anaesthesia) and in figure 3 for group III patients (neurolept anaesthesia). In both groups, premedication, intubation or sternotomy did not influence the catecholamine levels, which were in the normal range before the operation. Initiation of the cardiopulmonary bypass (S6), however, acted as a strong stimulus for the sympatho-adrenal system, especially in the
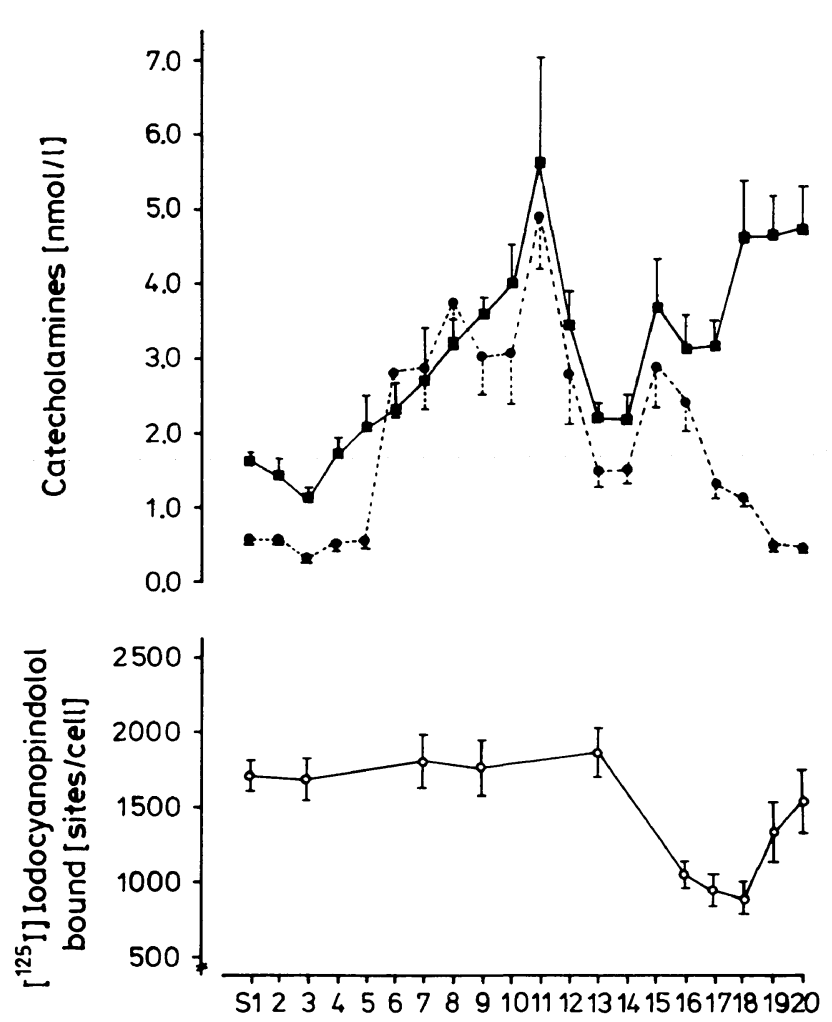

Fig. 2. Alterations in plasma concentrations of norepinephrine (squares) and epinephrine (closed circles) and in mononuclear leukocyte $\beta_{2}$-receptor densities (open circles) following cardiac surgery under enflurane anaesthesia. The sampling points are described in table 2 . patients under neurolept anaesthesia whose norepinephrine and epinephrine levels were significantly higher than those of the enflurane group at the sampling point $S 6$, and from $S 9$ to $S 15$ ( $p<0.05$, respectively). In group II, the disturbance of the sympathoadrenal system was maximal at the time of opening of the aorta (S11), when norepinephrine and epinephrine levels were 3.2 and 8.8 times higher than the postincision values, respectively. In group III, the maximal catecholamine response was observed after 1 to $2 \mathrm{~h}$ of cardiopulmonary bypass, the highest values being 9.7 (norepinephrine) and 28 (epinephrine) times higher than the basal values of non-anaesthetized patients. In both groups, the degree of stress decreased steadily from warming up beyond completion of the cardiopulmonary bypass until arrival in the intensive care unit. After extubation, epinephrine levels fell rapidly to control values, whereas the concentrations of norepinephrine steadily increased again and remained elevated throughout the postoperative period of 4 to 5 days. Plasma dopamine concentrations were between 0.2 and $0.6 \mathrm{nmol} / \mathrm{l}$ in non-anaesthetized patients in both groups. No significant changes were observed during the course of the operation (data not shown).
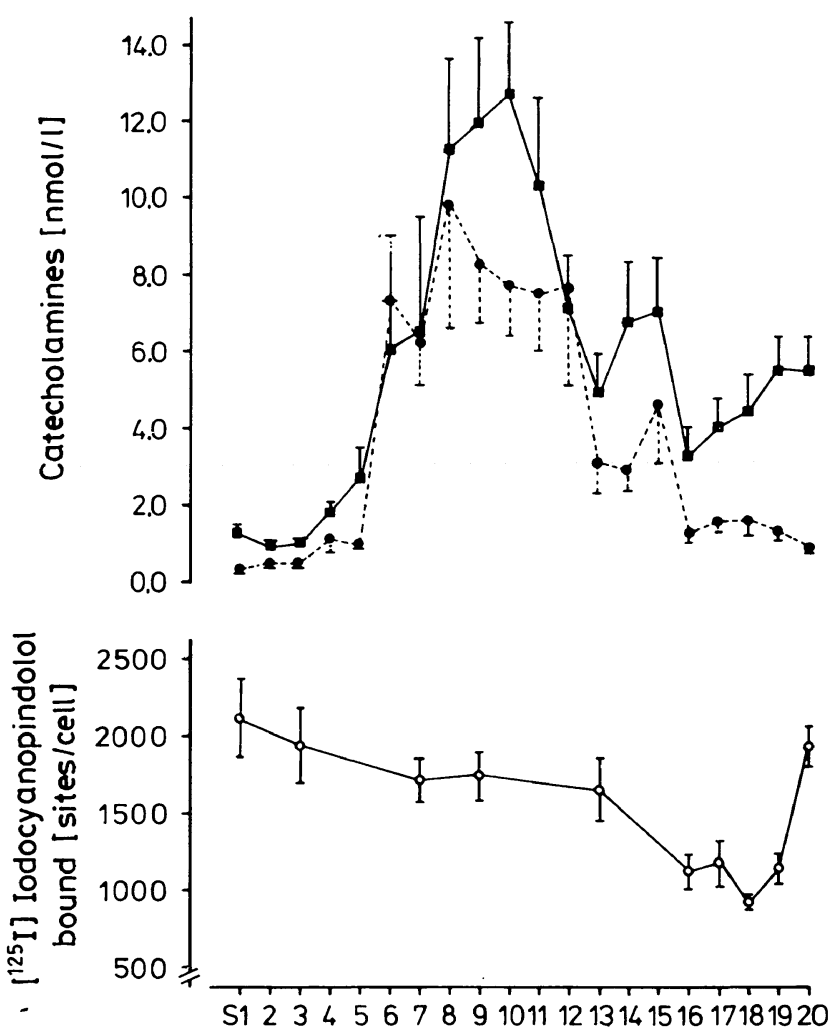

Fig. 3. Alterations in plasma concentrations of norepinephrine (squares) and epinephrine (closed circles) and in mononuclear leukocyte $\beta_{2}$-receptor densities (open circles) following cardiac surgery under neurolept anaesthesia. The sampling points are described in table 2 . 
Although the disturbances of the sympatho-adrenal system in the two anaesthetic schemes under investigation were quantitatively different, the changes in the densities of the mononuclear leukocyte $\beta_{2}$-receptors were comparable in both groups. The preoperatively determined $\beta_{2}$-receptor densities (1704 \pm 114 and $2113 \pm 200$ binding sites per cell in group II and III, respectively) remained. unchanged at least up to the completion of the cardiopulmonary bypass. The values of the $\beta_{2}$-receptor density at the sampling points $16,17,18$ in group II, and additionally at S19 in group III were significantly lower $(\mathrm{p}<0.05$, respectively) than the preoperative values; in groups II and III the maximal decreases were $44.5 \pm 10.6 \%$ and $53.2 \pm 6.6 \%$, respectively. Two days (in group II) or 4 to 5 days (in group III) after the cardiac surgery, $\beta_{2}$-receptor densities were already indistinguishable from the preoperative values. The preoperative dissociation constants $\left(K_{D}\right)$ for the binding of $\left[{ }^{125} \mathrm{I}\right]$ iodocyanopindolol to the $\beta_{2}$-receptors were $11 \pm 2 \mathrm{pmol} / \mathrm{l}$ (group II), and $12 \pm 2 \mathrm{pmol} / \mathrm{l}$ (group III), and these remained unchanged during and after cardiac surgery.

Mean values for arterial pressure ranged between 100 and $55 \mathrm{~mm} \mathrm{Hg}$ in the enflurane patients and between 102 and $65 \mathrm{~mm} \mathrm{Hg}$ in the patients under neurolept anaesthesia (fig. 4). No significant differences between the groups were observed. The mean numbers of granulocytes, lymphocytes and monocytes during the investigation are also shown in figure 4 . The response of these blood cells to the surgical stress was comparable between the groups. The proportions of $\mathrm{B}$ lymphocytes and $\mathrm{T}$ lymphocytes in the course of the investigation period determined in two patients of each group remained nearly constant despite the fluctuations in total lymphocyte counts (data not shown). Under either type of medication, surgical stress led to a continuous increase in the plasma concentration of cortisol from about $0.4 \mu \mathrm{mol} / 1$ preoperatively to around $1.1 \mu \mathrm{mol} / \mathrm{l}$ at extubation and $0.8-5.5 \mu \mathrm{mol} / \mathrm{l}$ 4 to 5 days postoperatively (data not shown).

We examined a possible correlation between the changes in the mononuclear leukocyte $\beta_{2}$-receptor densities and the magnitude and duration of the increases in epinephrine. A plot of the maximal increases in the epinephrine concentrations versus the corresponding maximal decreases in the mononuclear leukocyte $\beta_{2}$-receptor densities (calculated from the differences between preoperative and peak postoperative values) revealed no significant correlation between these two parameters in patients with hysterectomy and cardiac surgery (not shown). To investigate the effect of the duration of epinephrine elevation, the areas under the curves of the epinephrine

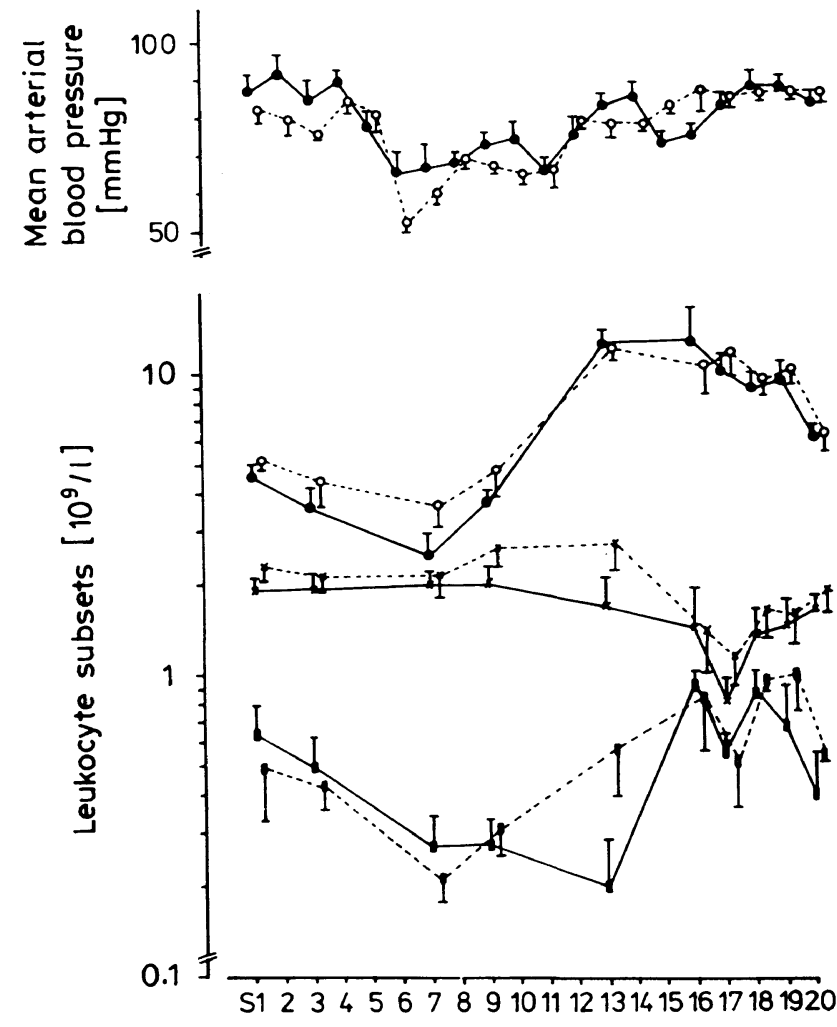

Fig. 4. Time course of the mean arterial blood pressure (upper part) and the mean number densities in peripheral blood (lower part) of granulocytes (circles), lymphocytes (crosses) and monocytes (squares) during cardiac operations and recovery, determined at the events listed in table 2. The solid lines represent the patients under neurolept anaesthesia, the dashed lines those under enflurane anaesthesia.

concentration profiles were calculated using the period from S2 to $\mathrm{S} 4$ (for group I) or from $\mathrm{S} 2-\mathrm{S} 18$ (group II and III). Again, no significant correlation of these values with the mononuclear leukocyte $\beta_{2^{-}}$ receptor densities could be found. Additionally, we could not detect any correlation of the decrease in mononuclear leukocyte $\beta_{2}$-receptors with the duration of the cardiopulmonary bypass or the whole operation.

To further exclude the possibility that the analgetic drug pethidine, which was given postoperatively to all patients investigated, might be responsible for the reduced $\beta_{2}$-receptor density on mononuclear leukocytes during this time period, we performed the following in vitro experiment: pethidine was added to blood diluted with RPMI 1640 medium $(1+1)$, and control and pethidine-containing samples were processed according to our typical protocol. In experiments using pethidine concentrations up to $30 \mathrm{mmol} / \mathrm{l}$ (a concentration that exceeds the concentration of the drug in plasma of the patients approximately by a factor of 30 to 100) and preincubation times up to 
$24 \mathrm{~h}$ at $37^{\circ} \mathrm{C}, \mathrm{B}_{\max }$ and $\mathrm{K}_{\mathrm{D}}$ values for the binding of $\left[{ }^{125} \mathrm{I}\right]$ iodocyanopindolol were indistinguishable from those of control samples. Furthermore, we found that the $\beta_{2}$-receptor densities on mononuclear leukocytes in fresh blood used for transfusions were indistinguishable from those observed preoperatively in the patients' blood.

There was no detectable relationship between the changes in catecholamine concentration and the mean arterial pressure. Additionally, we observed no correlation between the catecholamine levels and the postoperative haemodynamic instability in 2 cardiac patients who were transiently treated with dopamine infusions.

\section{Discussion}

The neuroendocrine response to surgical stress in man includes an increased activity of the pituitary-adrenocortical system and the sympathetic-adrenomedullary system (14). The activation of the latter system causes the release of norepinephrine from peripheral nerve terminals and of epinephrine from the adrenal medulla. Blood levels of these catecholamines are used as indices of the sympathetic activity. It has to be considered, however, that a sympathetic activation in the heart results in a concentration of norepinephrine at the sympathetic synapses of nerve and cardiac cells that can exceed plasma concentrations of norepinephrine by a factor of 10 to $1000(19,20)$. Therefore, the rates of down-regulation or reduction of adrenergic receptors on blood cells and tissue receptors may be different.

According to the hypothesis of Halter, Pflug \& Porter (21), adrenergic activation during surgical stress is primarily a response to afferent signals from the locus of trauma. In cardiac surgery, additional factors like hypothermia, the alteration of haemodynamics associated with the nonpulsatile blood flow during cardiopulmonary bypass, and myocardial hypoxia are present. These factors may explain the substantial differences between the catecholamine levels in the cardiac surgery patients and those in the hysterectomy patients observed in our study. In accordance with a report by Stanley et al. (22), we found a time-related increase in plasma concentrations of norepinephrine and epinephrine during cardiopulmonary bypass, suggesting that bypass and hypothermia result in a considerably greater perturbation of the sympatho-adrenal system than surgical stimulation. Additional sympathetic stimulation occurs during aortic crossclamping, presumably on the basis of the myocardial hypoxia.
As blood losses and alterations in blood pressure were of the same magnitude in both cardiac surgery groups investigated, the differences in the levels of norepinephrine and those of epinephrine between the two patient groups may be due to the differing abilities of the two anaesthetic schemes to decrease the sympathetic response to surgical stress. The experience of a number of authors suggests that plasma catecholamines may be affected by the depth of anaesthesia $(14,22)$. Therefore, the marked increase in the plasma concentration of catecholamines in the patients of group III may be a consequence of the fentanyl dose administered during the operation, which possibly was too low to maintain the original analgesia. With the application of considerably higher doses of fentanyl $(150 \mu \mathrm{g} / \mathrm{kg}$, vs. $5-10 \mu \mathrm{g} / \mathrm{kg}$ in this study), Zurick and colleagues (23) failed to demonstrate any difference in catecholamine levels between fentanyl and halothane- $\mathrm{N}_{2} \mathrm{O}$ anaesthesia. However, it cannot be decided from the results of this study whether the improved recovery following low-dose fentanyl anaesthesia represents a significant advantage, compared with the use of a higher dose. In reaching such a decision, the poor control of the depth of analgesia associated with low doses of fentanyl must be taken into consideration, as well as the resulting high catecholamine levels, which are especially threatening to patients with impaired myocardial function.

Catecholamine levels decreased sharply after the release of the aortic cross clamping and after arrival in the intensive care unit. This was followed by a continuous increase in norepinephrine concentrations in both patient groups after extubation up to 5 days postoperatively. Since the levels of norepinephrine in plasma determined 4,24 , and $48 \mathrm{~h}$ after hysterectomy were of the same magnitude as those observed $4 \mathrm{~h}$ to 5 days after cardiac surgery, it may be concluded that anaesthetic techniques and the extent of surgery appear to represent only minor influences on the sympatho-adrenal activity as compared with other factors, e.g., the extent of shivering, the perception of pain and the amount and type of analgesia administered.

The density of the $\beta_{2}$-receptors on mononuclear leukocytes in our patients remained constant during the operations, in spite of the marked stimulation of the adrenergic system as represented by the epinephrine concentration profile. This observation is not consistent with the report of Middeke et al. (24), who found a transient increase in the density of the mononuclear leukocyte $\beta_{2}$-receptors in a patient with a phaeochromocytoma within $30 \mathrm{~min}$ of the beginning of an acute episode of symptoms caused by a tenfold increase in the concentrations of epinephrine in 
plasma. However, although the sampling scheme in our study could not provide a continuous coverage of the time profile of the density of the mononuclear leukocyte $\beta_{2}$-receptors, the intervals (ca. $30 \mathrm{~min}$ ) were short enough to detect any transient increase in receptor densities within this time frame. The methodology used in our study determines the total number of surface and intracellular $\beta_{2}$-adrenergic receptors in leukocytes, because the radioligand and the competing unlabelled antagonist are both lipophilic, and have access to internalized receptors. Thus, our data do not permit conclusions with respect to the surface receptors only; however, the metabolism of the receptors is reflected by the total number of available $\left[{ }^{125} \mathrm{I}\right]$ iodocyanopindolol binding sites.

Postoperatively, a maximal decrement in the $\beta_{2}$-receptors of $27 \%$ was found in the hysterectomy group $4 \mathrm{~h}$ after the end of the operation, while the corresponding values observed in the cardiac surgery groups II and III were $45 \%$ and $53 \%$, respectively, after $24 \mathrm{~h}$. These decrements correspond to maximal increments in the plasma concentrations of norepinephrine and epinephrine of 2.7- and 2.8-fold in the hysterectomy patients, 3.2- and 8.8-fold in group II, and 9.7- and 28 -fold in group III of the cardiac surgery patients, respectively. However, no correlation between these parameters was found, even if the time profile using the values of the area under the curve was used for the analysis.

As reported previously, increased concentrations of $\beta$-agonists, observed following a postural change or an isoproterenol infusion in man (5), did not influence the mononuclear leukocyte $\beta_{2}$-receptor density. It is therefore necessary to seek factors other than increased catecholamine concentrations to explain the postoperative changes in receptor densities.

In our patients, surgery led to a marked leukocytosis (fig. 4), and it is conceivable that a shift in the distribution of $\mathrm{B}$ and $\mathrm{T}$ lymphocytes as well as in that of the T-cell subsets could also have occurred. B cells and monocytes contain twice as many $\beta_{2}$-adrenoceptors as $T$ cells (12), while T-helper lymphocytes possess only one fourth of the $\beta_{2}$-receptors found on $T$ suppressor cells (25); therefore, changes in the $B / T$ and monocyte/lymphocyte ratios could be manifested as an apparent change in receptor density. However, in accordance with most reports $(26,27)$, we found the $\mathrm{B} / \mathrm{T}$ ratio unchanged over the investigation period. In our study, we did not follow up any possible alterations in the relative distribution of $\mathrm{T}$-helper and T-suppressor cells. Yet, even a large shift from the normal 2:1 distribution of the helper and suppressor T-cells towards a $4: 1$ ratio could only result in a $10 \%$ decrease in the total mononuclear leukocyte $\beta_{2}$-adrenergic receptor density. Therefore, the influence of the T-helper/T-suppressor cell ratio is apparently only of minor importance for the changes observed here. Additionally, the time course of the monocyte concentration does not appear to be responsible for the fall in receptor densities.

Another explanation for the receptor alterations might be sought in the direct effects of drugs. In view of a $10 \%$ decrease in receptor density observed after in vitro incubation of mononuclear leukocytes with halothane (28), the pethidine given to our patients postoperatively in both surgical procedures may likewise cause a postoperative fall in receptor density. However, pethidine proved ineffective with respect to any receptor regulation in the in vitro experiments performed in this study. Endotoxin has been shown to produce a decrease of $\beta_{2}$-adrenergic receptor densities of up to $40 \%$ in the absence of catecholamines (29). Haemorrhagic shock (mean arterial pressure of $40-50 \mathrm{~mm} \mathrm{Hg}$ for 6 hours) in rats has further been shown to result in a $20 \%$ decrease in the number of $\beta$-adrenergic receptors (30). Altered membrane lipids and fluidity resulting from a direct action of halothane (28), and possibly also other narcotics, have also been proposed as a cause of receptor loss. These factors, which differ according to the type of surgery or anaesthesia, suggest that increased catecholamine concentrations are not the only causative agents for the decrease in mononuclear leukocyte $\beta_{2}$-receptors, and they may also explain the variable extent and time course of receptor reduction observed in hysterectomy and cardiac surgery.

The poor correlation between the elevated plasma catecholamines and the haemodynamic variables during cardiopulmonary bypass in this and other studies (31) may result from a decrease in cellular responses to adrenergic agonists, which might be expected from the reduction in the number of available $\beta_{2}$-receptors. The physiological implication of this will be a decrease in tissue sensitivity to agonists. A partial recovery of the response can only be achieved by increasing the relative occupancy of the $\beta$-adrenergic receptors using higher agonist concentrations. However, elevated plasma concentrations of catecholamines and of cortisol (which potentiates the vascular response to catecholamines) are apparently not sufficient for the recovery of a full biological response. Thus, it is frequently observed that a postoperative haemodynamic instability following cardiac surgery requires substantial pharmacological intervention, in spite of markedly elevated catecholamine levels. On the other hand, the finding of unchanged mean arterial pressure values, despite high catecholamine levels, should not hide 
the fact that these high levels have other metabolic consequences. The question therefore arises of whether cardiac surgery with high risk patients should be performed under neurolept anaesthesia.

\section{References}

1. Aarons, R. D. \& Molinoff, P. B. (1982) Changes in the density of $\beta$-adrenergic receptors in rat lymphocytes, heart and lung after chronic treatment with propranolol. J. Pharmacol. Exp. Ther. 221, 439-443.

2. Brodde, O.-E., Kretsch, R., Ikezono, K., Zerkowski, H.R. \& Reidemeister, C. J. (1986) Human $\beta$-adrenoceptors: Relation of myocardial and lymphocyte $\beta$-adrenoceptor density. Science 231, 1584-1585.

3. Aarons, R. D., Nies, A. S., Gerber, J. G. \& Molinoff, P. B. (1983) Decreased beta-adrenergic receptor density on human lmyphocytes after chronic treatment with agonists. J. Pharmacol. Exp. Ther. 224, 1-6.

4. Lefkowitz, R. J., Caron, M. G. \& Stiles, G. I. (1984) Mechanisms of membrane-receptor regulation. N. Engl. J. Med. 310, 1570-1579.

5. DeBlasi, A., Maisel, A. S., Feldman, R. D., Ziegler, M. G., Fratelli, M., DiLallo, D., Smith, D. A., Lai, C.-Y. L. \& Motulsky, H. J. (1986) In vivo regulation of $\beta$-adrenergic receptors on human mononuclear leukocytes: Assessment of receptor number, location, and function after posture change, exercise, and isoproterenol infusion. J. Clin. Endocrinol. Metab. 63, 847-853.

6. Ratge, D. \& Wisser, H. (1986) $\alpha$-and $\beta$-adrenergic receptor activity in circulating blood cells of patients with phaeochromocytoma: effects of adrenalectomy. Acta Endocrinol. $111,80-88$.

7. Hui, K. K. P. \& Conolly, E. (1981) Increased numbers of beta-receptors in orthostatic hypotension due to autonomic dysfunction. N. Engl. J. Med. 304, 1473-1475.

8. Maisel, A. S., Ziegler, M. G., Carter, S., Insel, P. A. \& Motulsky, H. J. (1988) In vivo regulation of $\beta$-adrenergic receptors on mononuclear leukocytes and heart. J. Clin. Invest. 82, 2038-2044

9. Brodde, O.-E., Daul, A. \& O'Hara, N. (1984) $\beta$-Adrenoceptor changes in human lymphocytes, induced by dynamic exercise. Naunyn-Schmiedeberg's Arch. Pharmacol. 325, $190-192$.

10. Burman, K. D., Ferguson, E. W., Djuh, Y.-Y., Wartofsky, L. \& Latham, K. (1985) Beta receptors in peripheral mononuclear cells increase acutely during exercise. Acta Endocrinol. 109, 563-568.

11. Ratge, D., Wiedemann, A., Kohse, K. P. \& Wisser, H. (1988) Alterations of $\beta$-adrenoceptors on human leukocyte subsets induced by dynamic exercise: effect of prednisone. Clin. Exp. Pharmacol. Physiol. 15, 43-53.

12. Landmann, R. M., Muller, S. B., Perini, C., Wesp, M. \& Bühler, F. R. (1984) Beta-adrenergic receptors are different in subpopulations of human circulating lymphocytes. J. Recept. Res. 4, 37-50.

13. Eandi, M., Buraglio, M., Arduino, C., Viano, I., Sansalvadore, G. \& Arbinolo, M. A. (1984) Changes of lymphocyte beta-adrenergic receptors after surgical stress. Int. J. Clin. Pharm. Res. IV, 349-354.

14. Derbyshire, O. R. \& Smith, G. (1984) Sympathoadrenal responses to anaesthesia and surgery. Br. J. Anaesth. 56, $725-739$

15. Hamberger, B. \& Järnberg, P.-O. (1983) Plasma catecholamines during surgical stress: differences between neurolept and enflurane anaesthesia. Acta Anaesthesiol. Scand. 27, $307-310$.

16. Rosenberg, J. S., Weiss, E. \& Wilding, P. (1984) Immunogold staining: Adaptation of a cell-labelling system for analysis of human leukocyte subsets. Clin. Chem. 30, $1462-1466$.

\section{Acknowledgement}

This study was supported by the Robert-Bosch-Stiftung, Stuttgart, FRG. We are grateful to Mrs. L. Schleher for secretarial assistance.

17. Ratge, D., Baumgardt, G., Knoll, E. \& Wisser, H. (1983) Plasma free and conjugated catecholamines in diagnosis and location of pheochromocytoma. Clin. Chim. Acta 132, $229-243$.

18. Ratge, D., Augustin, R. \& Wisser, H. (1987) Plasma catecholamines and $\alpha$ - and $\beta$-adrenoceptors in circulating blood cells in patients on continuous ambulatory peritoneal dialysis. Clin. Nephrol. 28, 15-21.

19. Kopin, I. J., Zukowska-Grojec, Z., Bagorh, M. A. \& Goldstein, D. S. (1984) Estimation of intrasynaptic norepinephrine concentrations at vascular neuroeffector junctions in vivo. Naunyn-Schmiedeberg's Arch. Pharmacol. 325, 298 305.

20. Bevan, J. A. (1978) Norepinephrine and the presynaptic control of adrenergic transmitter release. Fed. Proc. 37, $187-190$.

21. Halter, J. B., Pflug, A. E. \& Porte, D. (1977) Mechanism of plasma catecholamine increases during surgical stress in man. Clin. Endocrinol. Metab. 45, 936-944.

22. Stanley, T. H., Berman, L., Green, O. \& Robertson, D. (1980) Plasma catecholamine and cortisol responses to fentanyl-oxygen anaesthesia for coronary-artery operation. Anesthesiology 53, 250-253.

23. Zurick, A. M., Urzna, J., Yared, J.-P. \& Estafanous, F. G. (1982) Comparison of hemodynamic and hormonal effects of large single-dose fentanyl anesthesia and halothane/nitrous oxide anesthesia for coronary artery surgery. Anesth. Analg. 61, 521-525.

24. Middeke, M., Lohmüller, G., Remien, J., Kirzinger, S. \& Holzgreve, H. (1988) Acute regulation of lymphocyte $\beta$ adrenergic receptor activity in pheochromocytoma. Klin. Wochenschr. 66, 187-189.

25. Khan, M. M., Sansoni, P., Silverman, E. D., Engleman, E. G. \& Melmon, K. L. (1986) Beta-adrenergic receptors on human suppressor, helper, and cytolytic lymphocytes. Biochem. Pharmacol. 35, 1137-1142

26. Lee, Y.-T. N., Marshall, G. J. \& Jalaba, J. (1978) Effect of operation on B and T lymphocyte counts. J. Surg. Oncology $10,289-297$.

27. Hamid, J., Bancewicz, J., Brown, R., Ward, C., Irving, M. H. \& Ford, W. L. (1984) The significance of changes in blood lymphocyte populations following surgical operations. Clin. Exp. Immunol. 56, 49-57.

28. Marty, J., Nivoche, Y., Nimier, M., Rocchiccioli, L., Luscombe, F., Henzel, D., Loiseau, A. \& Desmonts, J. M. (1987) The effects of halothane on the human beta-adrenergic receptor of lymphocyte membranes. Anesthesiology 67, 974-978.

29. Liu, M. S. \& Gosh, S. (1983) Changes in $\beta$-adrenergic receptors in dog livers during endotoxic shock. Am. J. Physiol. 244, R718-R723.

30. Yahagi, M., Mizunachi, K. \& Kawabata, T. (1987) Down regulation of cardiac $\beta$-adrenergic receptors in hemorrhagic shock. Circ. Shock 21, 295-299.

31. Reves, J. G., Karl, R. B., Bunner, E. E., Tosone, E., Smith, L. R., Samuelson, P. N., Dreusch, G. R. \& Oparil, S. (1982) Neuronal and adrenomedullary catecholamine release in response to cardiopulmonary bypass in man. Circulation $66,49-55$

Prof. Dr. Dr. H. Wisser

Department of Clinical Chemistry

Robert-Bosch-Krankenhaus

Auerbachstraße 110

D-7000 Stuttgart 50 